\title{
ECOLOGICAL AND OTHER METHODS OF AGRICULTURAL PRODUCTION. DECISION MAKING WITH AHP
}

\author{
Anna Greda * \\ Cracow University of Economics \\ Cracow, Poland \\ gredaa@uek.krakow.pl; greda.anna@ gmail.com
}

\begin{abstract}
Consumers are more and more interested in purchasing food products of the highest quality, which are safe, free from chemicals and pesticide, produced with methods that do not violate the natural environmental balance. For this reason a return to ecological food production methods is becoming more popular. The ecological products market is one of the fastest growing markets in EU countries. In Poland ecological crop methods compose the margin of agricultural production and ecological food occupies $0,2-0,3 \%$ of the food market. A market study carried out in Poland shows that from 2003 the market of ecological food has been developing, the number of ecological producers has been enlarging, and the sale of ecological food has been growing about $20-30 \%$ per year.

This paper presents a complex approach to the problem of optimal agricultural production method choice, taking into consideration all possible factors and their dependencies within BOCR (benefits, opportunities, costs and risks). The Analytic Hierarchy Processes (AHP) were applied to build and analyze the problem. Three alternatives were considered: (1) conventional agriculture (non ecological), (2) integrated agriculture (pro-ecological, organic - chemical) and (3) ecological agriculture. The proposed approach to the solution of the problem can be used in practice and be helpful for producers/farmers in considering if they should or not change conventional methods of food production to ecological or pro-ecological.
\end{abstract}

Keywords: ecological, conventional and integrated agriculture, decis ion making, Analytic Hierarchy Process (AHP)

\section{Introduction}

The intensifying symptoms of the ecological crisis in the contemporary world mean that in many countries ways of preventing unfavourable environment and food contamination phenomena are being sought. Not only does industry contribute to this contamination, but also agriculture, which uses artificial fertilizers and toxic pesticides. In order to produce the maximum amount of food at the lowest cost, production is being intensified at the same time forgetting about soil "endurance boundaries" and well-being of animals. The countries which are agricultural powers have used large quantities of fertilizers and chemical substances for years and have led an increased number of animals per every hectare of farmland. Such actions have had an impact on the environment. This is why currently there is a tendency to eliminate harmful chemical substances, replacing them with organic farming methods, which are more thought through and rational. Recently we can observe a number of environmentally-friendly trends in agricultural production. Environmentally-friendly production systems are by no means a regression to traditional or primitive methods, but are the result of farmers work and scientific research.

\footnotetext{
* Corresponding author
} 
The aim of this work is the presentation of possibilities of solving the problem concerned with the choice of the optimum agricultural production method using the AHP method.

This paper presents initial results of researches, which plan to be continued with farmers in Poland who are during transposition or have already transposed on ecological methods of agriculture production.

\section{Methodology - Anal ytic Hierarchy Processes}

To solve the problem was used the Analytic Hierarchy Process (AHP). This is one of the fastest developing and most known mathematical methods in recent years, used for solving multicriteria decision problems. The AHP combine some mathematical and psychological concepts. This method basis on three axioms: (1) reciprocal opinions, (2) homogeneity, (3) dependence between elements from lower level of the hierarchy with the elements located on upper levels (Saaty, 2001). Its applications enclose wide range of decision problems from many disciplines e.g.: economics, management, technology, politics, social problems (Greda, 2009; Greda, 2010). This method has been used by organizations known worldwide like: NASA, US Navy, US Army, USDA Rural Development, JIEDDO, Nuclear Regulatory Commission, National Instutues of Health (NIH), IBM, Johnson\&Johnson, ebay, National Football League (NFL). Professor Thomas L. Saaty as a creator of the AHP/ANP got many prestigious awards for the development of the Analytic Hierarchy Process and the impact of his lifelong research on several disciplines.

\section{AHP/ANP Decision Model}

The AHP model of optimal agricultural production method choice was elaborated, follow ing a review of the existing studies and such of a combination of various evidence and theories, regarding possibly whole existing knowledge about agricultural production and their development towards sustainable agriculture by using principles of ecology, rebuilding the harmonious relationship between human being and nature (Zakowska - Biemas, 2003; Szltysek, 2004; Act of 25.06.2009 r. about ecological agriculture; Siebenneicher, 2001; Luczka - Bakula, 2007).

Application of the Analytic Hierarchy Process allows identification and prioritization of factors, in terms of benefits, opportunities, costs and risks (B,O,C,R), contributing to select optimal agricultural production method. The optimal agricultural production method can be defined as agricultural practices that have acceptable environmental impacts. The main environmental impacts of agriculture come from the conversion of natural ecosystems to agriculture, from agricultural nutrients that pollute aquatic and terrestrial habitats and groundwater, and from pesticides, especially bioaccumulating or persistent organic agricultural pollutants. Agricultural nutrients enter other ecosystems through leaching, volatilization and the waste streams of livestock and humans. Pesticides can also harm human health, as can pathogens, including antibiotic-resistant pathogens associated with certain animal production practices (Tilman et al., 2002).

Each second level, of every AHP decision hierarchy of optimal agricultural production method choice (fig. 1 - 4) took into account four main criteria: environmental, social, economic and marketing factors. On the third level of the structure subcriteria were adopted in relation to the main criteria, whereas the fourth level consists of alternatives, which present various methods of agricultural production:

A. Conventional farming (non ecological) - this is the kind of farming which dominated the $20^{\text {th }}$ century and which accounts for most farming today. In conventional farming, chemical plant protectants, chemical fertilizers and intensive mass animal farming are used.

B. Integrated farming (pro-ecological, organic - chemical) - an approach to farming that combines the best of traditional methods with modern technology, to achieve high productivity 
with a low environmental impact (www.agriculturedictionary.com). This is a method between conventional and organic agriculture. It tries to prevent damages, caused by insects or weeds and diseases, by: crop rotation, using stronger races or types, that are more resistant against diseases, quick covering of leaves, to control the weed, giving low mineral gifts, to strengthen the plants, measuring nitrogen in the soil and leaf stalk, that way it can be known how many (animal) manure has to be added, mechanic weed control (by harrowing and weeding), only spraying chemical pesticides in the row, and not in between two rows, using thresholds for pest (for example: aphids) control (www.homeplanet.nl).

C. Ecological farming (organic) - is the form of agriculture that relies on techniques such as crop rotation, green manure, compost and biological pest control to maintain soil productivity and control pests on a farm. Organic farming excludes or strictly limits the use of manufactured fertilizers, pesticides (which include herbicides, insecticides and fungicides), plant growth regulators such as hormones, livestock antibiotics, food additives, and genetically modified organisms (Directorate General for Agriculture and Rural Development of the European Commission - www.ec.europa.eu).

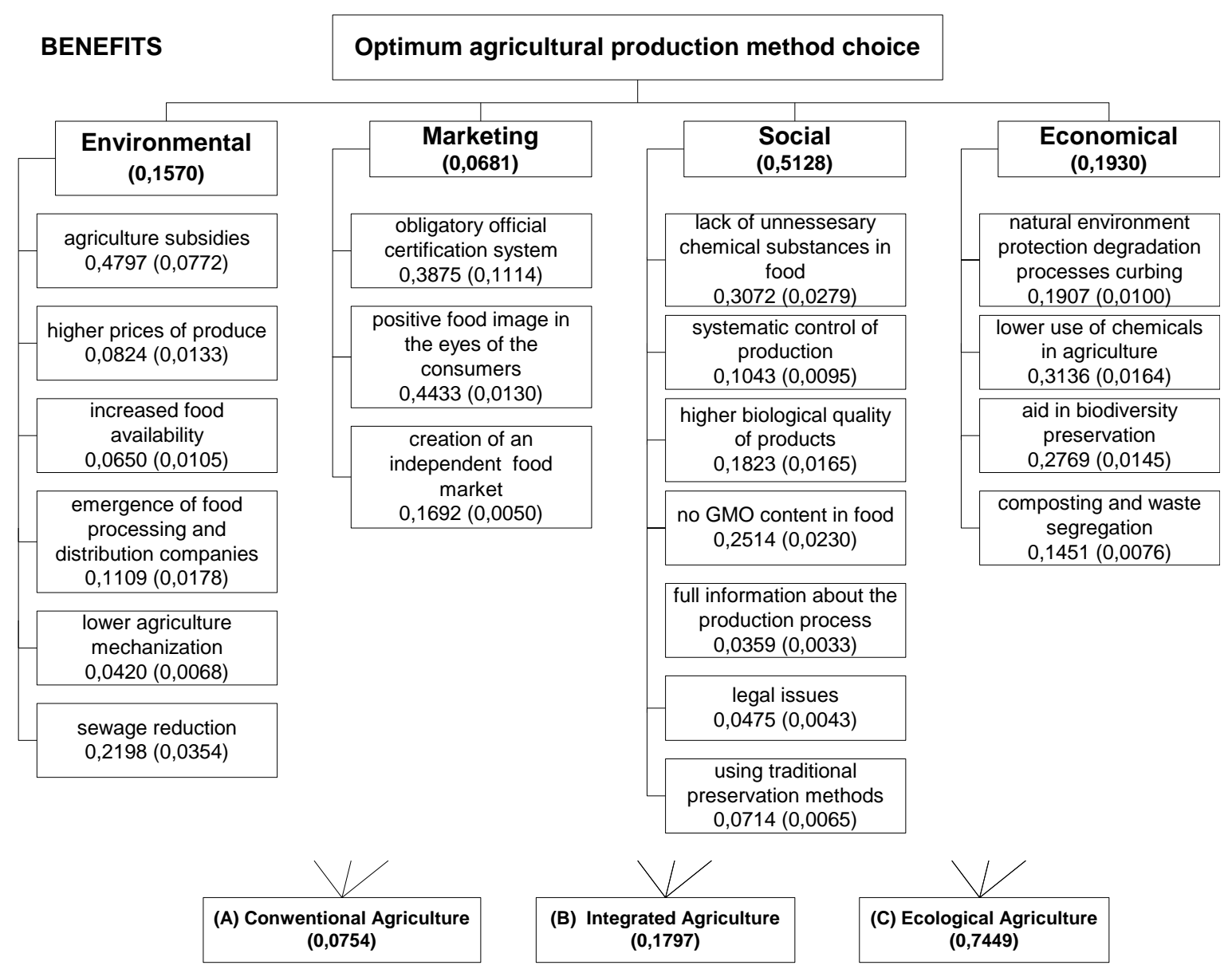

Figure 1. AHP model for Benefits of „optimum agricultural production method choice” 


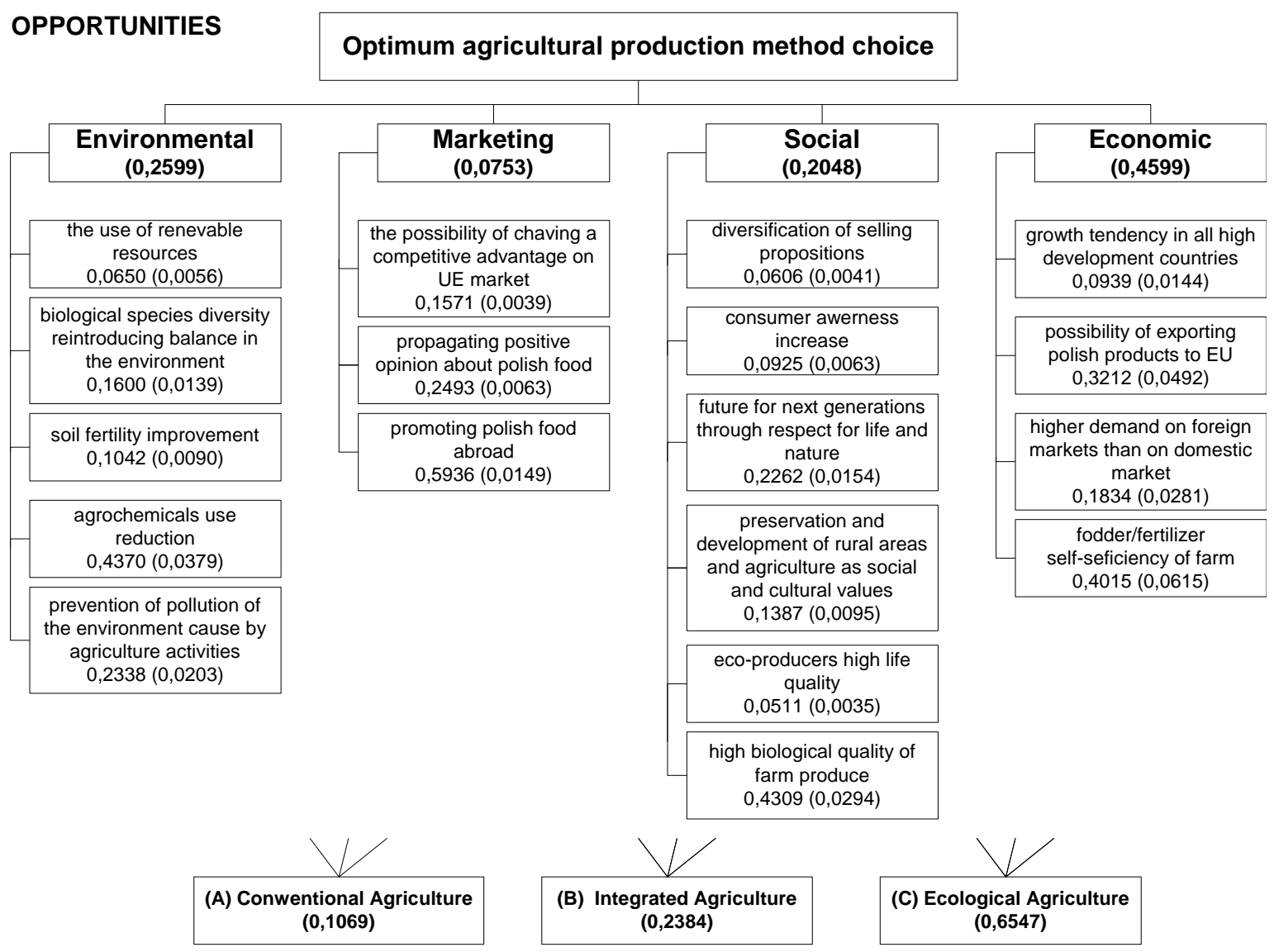

Figure 2. AHP model for Opportunities of „optimum agricultural production method choice”

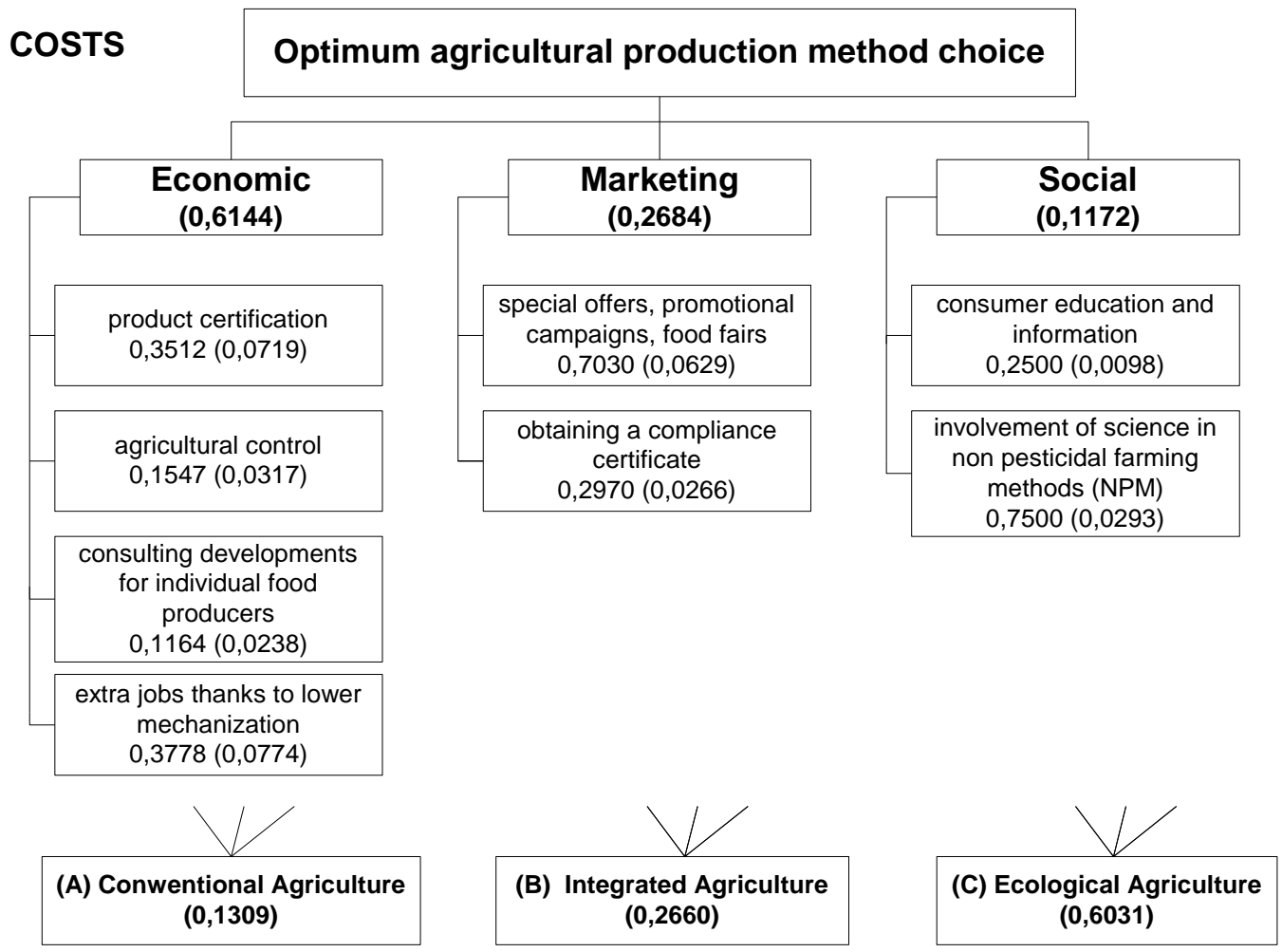

Figure 3. AHP model for Costs of „optimum agricultural production method choice” 


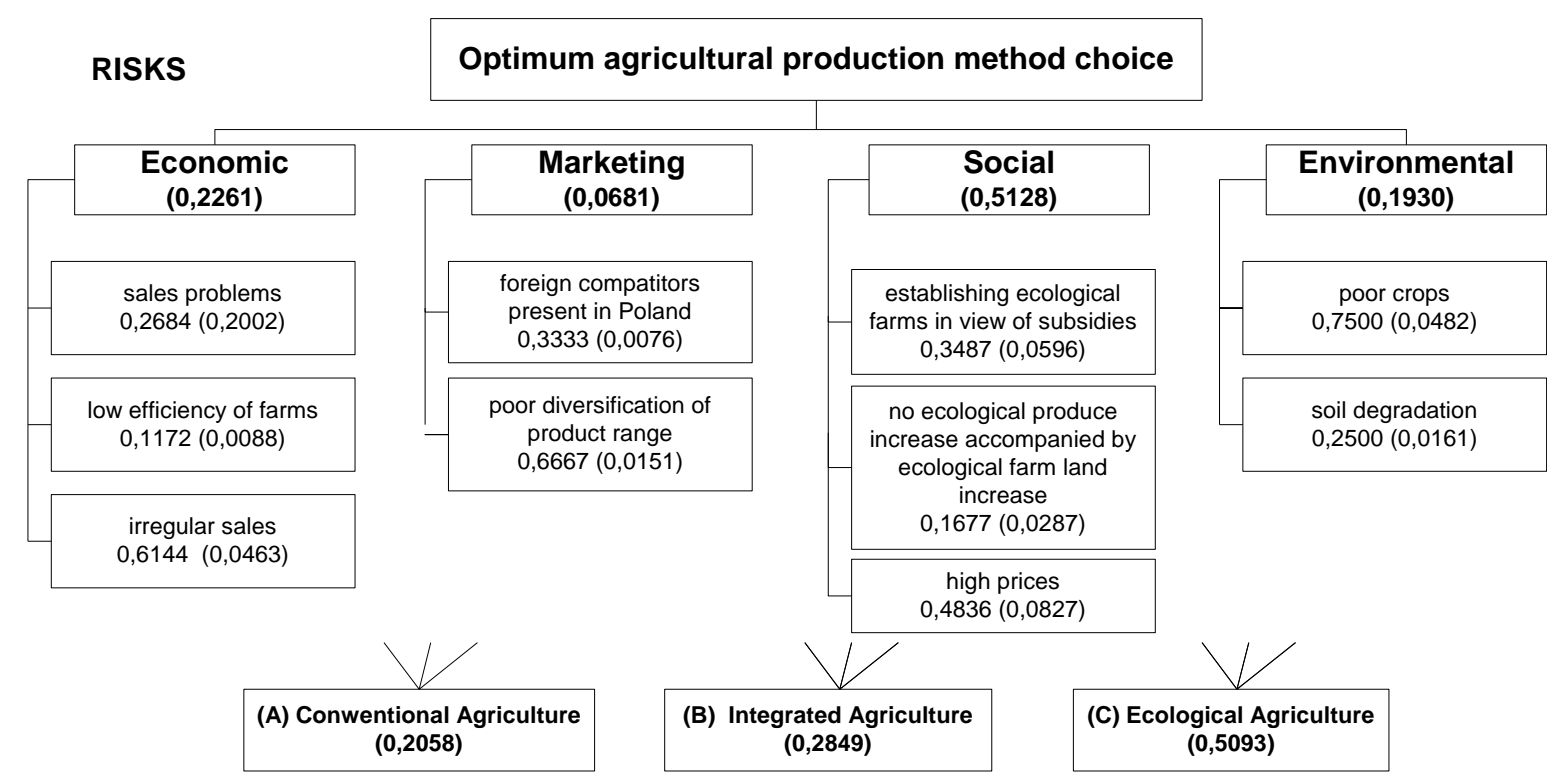

Figure 4. AHP model for Risks of „optimum agricultural production method choice”

\section{Analysis and Results}

Construction of the BOCR model, was followed by its analys is using pairwise comparisons of the elements on every level of decision models, according to the Saaty's 9-point scale. To make the final decision, which is optimal agricultural production method choice, all factors from the BOCR models were analyzed using Super Decisions software. This program apart from facilitating the calculation of priorities allows for, amongst others, estimating the inconsistency coefficient C.R. The CR index was lower than $10 \%$ in all pairwise comparisons matrices of B,O,C,R models. The objective is to find the alternative that is most beneficial and offers most opportunities while at the same time representing the lowest risk and the lowest costs variant.

Figures 1 to 4 represent In turn hierarchical models of: benefits, costs, opportunities and risk. In these figures subcriteria priority values are presented in the brackets in the fulfilment of the main aim. Detailed calculation results for each main criteria and subcriteria of the AHP decision models have not been discussed out of editorial considerations.

In order to choose the optimum agricultural production method the values obtained for each of the alternatives from the benefit and opportunity models were divided by the analogical values from the costs and risk models (BO/CR). The end values for each of the alternatives have been collected in table 1. What follows is that the best alternative which meets the criteria and subcriteria of the described models to the largest extent is an ecological agricultural production method. This variant obtained the highest priority equal to 0.6475 . The ecological agricultural production method emerged to be a solution that yields the farmer the most opportunitites $(0.6547)$ and benefits $(0,7449)$. However, it is also the solution with the highest cost $(0,6030)$ and risk $(0,5093)$ in comparison to other alternatives considered in the described decision models.

Table 1. Final results of the ANP analysis

\begin{tabular}{|c|c|c|c|c|c|}
\hline Alte rnatives & Benefits & Cos ts & Opportunities & Ris ks & $\begin{array}{c}\text { Formula } \\
\text { BO/CR }\end{array}$ \\
\hline A - Conventional & 0,0758 & 0,1201 & 0,1089 & 0,2058 & 0,1220 \\
\hline B - Integrated & 0,1797 & 0,2640 & 0,2304 & 0,2850 & 0,2304 \\
\hline C - Ecological & 0,7449 & 0,6030 & 0,6547 & 0,5093 & 0,6475 \\
\hline
\end{tabular}

Source: Own elaboration 
Higher costs and the risk stemming from switching agricultural activity to ecological methods are caused by the necessity of taking into consideration a period of transition while changing the current (conventional) methods of farming to ecological ones, smaller by around $1 / 3$ productive efficiency, more time consumption, higher production costs, higher (by at least 30 per cent) ecological products' prices, the small sizes and scattering of ecological farms and the lack appropriate marketing. Hence larger farmers' flexibility, the forming of co-operatives, which are able to guarantee steady supplies, a wider choice range and stock quantities.

In accordance with the AHP decision process ecological production methods have turned out to be the optimum method despite the high costs and risk priorities obtained. Analysing the other alternatives it can be concluded that the second in line is the integrated agricultural production method $(0,2304)$ combining elements of ecological and conventional production, whereas conventional methods were in the last place $(0,1220)$.

Thus farmers activities should head towards ecologization of agricultural production, which in the long run should first of all yield benefits to the producers, the society and the surrounding environment.

Taking into account the results of the conducted analysis using the AHP method as well as serious thought and observations of other researchers it can be concluded that total ecologization of agriculture is not entirely possible. Around the world the share of ecological agriculture does not exceed a few per cent. However, it constitutes an important complement to conventional farming. Agricultural production ecologization can be regarded not so much as a revolution but as accelerated evolution eliminating negative effects of agricultural intensification, which took place in the 1960s and 1970s. Its determinants - were farmland remembrement, electrification, introduction of pesticides and artificial fertilizers, mechanization, melioration and so on. Farming and rural life has ceased to be a way of life and has become "production". Ecological farming is first of all an alternative to the "large" farming technology and agrochemistry, responsible for the contamination of the environment, disruption of agricultural biocenoses biological immunity mechanisms and the production of excessive amounts of substandard biologically food, which does not guarantee health to the people consuming it.

Taking into account the fact that Polish agriculture uses 2-3 times less mineral fertilizers and 7 times less pesticides than an average European Union member country, integrated agricultural methods should also be considered. Amongst others, the condition of the natural environment in Poland, which is better than in the EU, is a strong argument for such production methods. Only $2 \%$ of soils in Poland have been excluded from cultivation due industrial pollutions.

\section{Conclusions}

On the basis of the described decision models and the conducted AHP analysis, presented above European agricultural production methods as well as the existing consumer preference connected with the desire to return to food trends prevailing as recently as a dozen years ago - natural, unprocessed products containing as little artificial additives as possible the following conclusions can be drawn as far as the direction of agricultural development in Poland is concerned. Similar conclusions have been drawn by other researchers of this subject (Majchrzycki, Baum, 2002):

1. Conventional (highly effective) farming, based on highly intensive production methods; that is high use of pesticides and artificial fertilizers, using growth stimulants in animal production has limited development potential. One of the reasons is excessive food production. Poland is currently self-sufficient to a very large extent as far as food is concerned. Further production growth entails the necessity of expanding exports, and this in turn leeds to higher export subsidies. Another reason are legal constraints in the field of environmental protection. Highly intensive farming also leads to limited employment opportunities in rural areas. It would result in even higher unemployment in rural areas.

2. Ecological agriculture - from the perspective of natural resources preservation and the conducted multicriteria decision analys is is the optimum agricultural production method. It does not cause environmental degradation, enables the production of food which is 
wholesome. Agriculture ecologization would enable the employment of a large number of people who should leave rural areas. Market research in Poland has shown that since 2003 the ecological food market has been developing by $20-30 \%$ every year. However, like in other European countries it is necessary to undertake actions stimulating switching to ecological production methods amongst the producers, ecological food processing development and promotion of ecological food. An incentive to switching to such production are amongst others a bit higher ecological products' prices as well as subsidies from Poland and the EU. However, complete ecologization of agriculture is rather impossible. One of the barriers is the low efficiency of ecological farming as well as the price barrier of ecological products for the Polish customer. The majority of Poles simply cannot afford to buy more expensive ecological food. This farming method is nevertheless a vital complement of conventional agriculture.

3. Integrated farming - in accordance with the results obtained on the basis of an AHP analysis constitutes the second in line, after ecological farming solution, in the nearest future should be propagated and introduced. It is a compromise between conventional and ecological farming. It will allow us to retain food safety of the country and will enable the production of food satisfying quality parameters at reasonable prices, acceptable to consumers. In comparison to conventional farming it contributes to the degradation of the environment to a smaller extent and makes preserving the natural character of rural areas possible.

4. The presented solution to the problem using the AHP method may be extremely useful and helpful for producers/farmers in taking difficult decisions concerning action taking towards ecologization of agricultural production as well supplying indispensible information facilitates rational decision making.

\section{REFERENCES}

1. Directorate General for Agriculture and Rural Development of the European Commission www.ec.europa.eu.

2. Greda A. (2010). The choice of effective quality management system in food industry with using the Analytic Network Process. Problemy Jakości. Nr 7, s. 16 - 28 (in polish).

3. Greda A. (2009). Application of the AHP/ANP in food quality management, [w:] ISAHP 2009, Conference Handbook, July 29 - August 1, 2009, Pittsburgh, Pennsylvania, USA.

4. Luczka-Bakula W. (2007). The ecological food market: determinants and conditioning of development. Publ. PWE. Warsaw (in polish).

5. Majchrzycki D., Baum R. (2002). Directions of agriculture development in perspective of accession to European Union. [w:] www.ppr.pl/artykul-kierunki-rozwoju-rolnictwa-wperspektywie-przystap-2887.php z dnia 19.06.2002 (in polish)..

6. Saaty T. L. (2001). Decision Making with Dependence and Feedback. The Analytic Network Process. RWS Publications. Pittsburgh PA.

7. Siebenne icher G.E.: Textbook of ecological agriculture. Publ. WNT. Warsaw 1997 (in polish).

8. Szoltysek K. (2004). Outline of problems of ecological food. Publ. AE im. Oskar Lange in Wroclaw.

9. Tilman, D., Cassman, K.G., Matson, P.A., Naylor, R. and Polasky, S. 2002. Agricultural sustainability and intensive production practices. Nature 418: 671-677.

10. Act of 25.06.2009 r. about ecological agriculture (Dz.U. Nr nr 116, poz. 975) (in polish).

11. www.agriculturedictionary.com

12. www.homeplanet.nl

13. Zakowska - Biemas S., Gutkowska K. (2003). Rynek żywności ekologicznej w Polsce $i w$ krajach UE. Publ. SGGW. Warsaw (in polish). 